\title{
In vitro maturation may prevent the cancellation of in vitro fertilization cycles in poor responder patients: A case report
}

\author{
In vitro matürasyon, zayıf over cevabı veren hastalarda in vitro fertilizasyon \\ sikluslarinin iptalini engelleyebilir: Vaka raporu
}

\author{
Ender Yalçınkaya ${ }^{1}$, Eray Çalışkan², Özcan Budak ${ }^{1}$ \\ ${ }^{1}$ Assisted Reproduction Unit, Faculty of Medicine, Kocaeli University, Kocaeli, Turkey \\ ${ }^{2}$ Department of Obstetrics and Gynecology, Faculty of Medicine, Kocaeli University, Kocaeli, Turkey
}

\section{Abstract}

In vitro maturation (IVM) is a promising technique that is used for the maturation of immature oocytes in laboratory conditions and preferred for use in patients with a diagnosis of polycystic ovary syndrome (PCOS) as an alternative to conventional in vitro fertilization (IVF) treatment. In this report, we present a case who surprisingly showed insufficient response to gonadotrophin stimulation during IVF treatment and whose cycle was retrieved from cancellation by using the in vitro maturation technique. As a result, we conclude that IVM may be a good option not only for PCOS patients, but also for poor responders. (J Turkish-German Gynecol Assoc 2013; 14: 235-7)

Key words: In Vitro maturation, in vitro fertilization, gonadotrophins

Received: 01 February, 2013

Accepted: 10 March, 2013

Available Online Date: 10 July, 2013

\section{Özet}

In vitro matürasyon (IVM), immatür oositlerin laboratuvar koşullarında olgunlaştırılması için umut vadeden bir tekniktir ve çoğunlukla polikistik over (PKO) tanısı koyulmuş hastalarda konvansiyonel in vitro fertilizasyon (IVF) tedavisine bir alternatif olarak tercih edilmektedir. Bu raporda, IVF tedavisi sırasında kullanılan gonadotropinlere sürpriz şekilde zayıf over cevabı veren ve aynı siklusu in vitro matürasyon tekniği kullanılarak iptal olmaktan kurtarlan bir vakayı sunuyoruz. Bu vakanın sonucu olarak, IVM'in sadece polikistik overli hastalar için değil, aynı zamanda zayıf over cevabı veren hastalar için de iyi bir tedavi seçeneği olabileceği sonucuna vardik. (J Turkish-German Gynecol Assoc 2013; 14: 235-7)

Anahtar kelimeler: İn vitro matürasyon, in vitro fertilizasyon, gonadotropinler

Geliş Tarihi: 01 Şubat 2013

Kabul Tarihi: 10 Mart 2013

Çevrimiçi Yayın Tarihi: 10 Temmuz 2013

\section{Introduction}

Assisted reproduction programmes frequently use ovulation stimulation protocols in order to increase the number of oocytes available for fertilization. However, ovarian hyperstimulation with exogenous gonadotrophins produces many risks for patients such as ovarian hyperstimulation syndrome or cycle cancellation due to risk of hyperstimulation, delayed response or improper use of drugs by patients. Under these circumstances, in vitro maturation (IVM), fertilization and embryo transfer may provide an alternative to cancellation of these cycles. Moreover, the development of the in vitro maturation technique could provide a new strategy for assisted reproduction, enabling cost reduction and minimizing concerns about a possible association between the use of ovulation-inducing drugs and their side effects (1).

The IVM technique was first demonstrated by Pincus and Enzmann (1935) and later by Edwards (1969). In the last two decades, many improvements in clinical and laboratory aspects have been achieved. However, its efficiency is still suboptimal compared to controlled ovarian hyperstimulation cycles in terms of the number of mature oocytes obtained, embryo developmental competence and implantation rates. As success of the technique increases, the indications of IVM are widening to include various diagnoses of infertility (2).

In particular, women with polycystic ovaries and those who have a previous history of a hyperstimulation reaction during conventional controlled ovarian stimulation have been considered good candidates for IVM. Diminished ovarian reserve with a poor response to controlled ovarian stimulation is a difficult part of in vitro fertilization (IVF) practice to manipulate and yields low success rates. Poor ovarian response in IVF has been characterised as a low number of follicles seen in ultrasound scans, high basal serum follicle stimulating hormone (FSH) concentrations and fewer than five oocytes obtained in a stimulated cycle (3).

Some poor responders appear to respond to stimulation but have a low oestrogen level of a few or slow-growing follicles. 
These patients seem resistant to gonadotrophin stimulation and require extended stimulation time and a higher dose of gonadotrophins. Data are limited on in vitro maturation treatment of poor responders or patients with retarded follicular development during a conventional stimulation IVF cycle (4).

In this report, we presented a case in which the in vitro maturation of oocytes obtained from a patient who showed inefficient response to high doses of exogenous gonadotrophins during an IVF treatment regimen resulted in fertilization and pregnancy.

\section{Case Report}

The patient admitted to Kocaeli University IVF Unit with a complaint of diminished ovarian reserve. She was 36 years old and had 1-2 antral follicles in each ovary at the basal ultrasonography. Her basal hormone levels were as follows: FSH, $2.8 \mathrm{mIU} /$ $\mathrm{mL}$; luteinizing hormone (LH), $2.9 \mathrm{mIU} / \mathrm{mL}$; estradiol (E2), 13.06 $\mathrm{pg} / \mathrm{mL}$; and prolactin, $4.06 \mathrm{ng} / \mathrm{mL}$. A microdose flare up protocol was planned for the patient. The starting recombinant FSH dose (Gonal $\mathrm{F}^{\circledR}$, Serono, Italy) was 375 units; however, the dose was increased up to 525 units since the patient's ovaries did not respond adequately to the first applied dose. On day 11, the dose used was 525 units, but the mature follicle was only 11.5 $\mathrm{mm}$ in diameter, which was unexpected. Oestradiol level at day 11 was $501 \mathrm{pg} / \mathrm{mL}$, which was not correlated with the mature follicle count. Her doctor offered two choices for the patient. First was the cancellation of the cycle and the other was the collection of the oocytes followed by an attempt to mature them in vitro. The patient selected the latter and did not want the cycle to be cancelled. Human chorionic gonadotrophin (hcg) was administered on day 11 and the oocyte collection procedure was performed in the $36^{\text {th }}$ hour of hcg administration and 3 oocytes were collected. The endometrial thickness of the patient was $7.9 \mathrm{~mm}$ at the time of oocyte collection. After denudation, it was found that one of the oocytes was metaphase II (MII), one was metaphase I (MI) and the third one was germinal vesicle (GV) stage. Intracytoplasmic sperm injection (ICSI) was performed on the MII oocyte, and the others were incubated in oocyte maturation medium (Sage; CooperSurgical, USA ). The fertilization check was done after the $18^{\text {th }}$ hour and it was observed that the mature oocyte was not fertilised. The maturation check was done at the $20^{\text {th }}$ hour and it was observed that the remaining two oocytes were matured to MII phase. Newly matured oocytes were microinjected in the afternoon and the fertilization check was done on the next day (after 18 hour of sperm injection). It was noted that one of the oocytes was $2 \mathrm{pn}$ and the other was $3 \mathrm{pn}$. The $2 \mathrm{pn}$ zygote was transferred to the patient on the same day. After 13 days, the blood hcg level was measured and it was observed that patient had a hcg level of 136 which indicated pregnancy. After two weeks of hcg measurements, a sac was seen at ultrasonography and a foetal heart beat was seen after two weeks; this was an indicator of a singleton clinical pregnancy.

\section{Discussion}

Of the oocytes retrieved after ovulation induction during IVF treatment, approximately $20 \%$ are found to be immature (GV and MI stage). These oocytes are not used for intracytoplasmic sperm injection during routine laboratory applications and are discarded due to their reduced fertilization potential and embryo development under current culture conditions. However, these oocytes are useful for studies that aim to explain the mechanisms of in vitro maturation of human oocytes (5). IVM appeared as a theoretically attractive method for obtaining mature oocytes for IVF when it was first announced. However, the efficiency of current IVM techniques are currently thought be suboptimal in terms of the number of mature oocytes obtained, embryo developmental competence and implantation rates (6), as well as the outcome of fertilization is often poor with standard in vitro-matured oocytes (7). Therefore, several clinical alterations such as FSH and hcg priming before oocyte collection, rearrangements in the maturation period and timing of aspiration have been made to improve the quality of IVM oocytes.

To date, several studies have reported the effects of FSH and hcg priming on in vitro maturation outcomes and have given conflicting results. In a study by Fadini et al. (8), where oocytes were primed with different gonadotrophin regimens before in vitro maturation, it was found that 3-day FSH priming did not result in a higher number of oocytes retrieved. In this study, FSH priming alone did not seem to promote oocyte maturation or improve the fertilization rate. This finding was in accordance with Mikkelsen's study in 1999 (9) in which pre-treatment of patients with recombinant FSH did not increase the number of oocytes retrieved. Accordingly, Lin et al. (10) could not find any beneficial effect of FSH priming on the number of oocytes retrieved, maturation and fertilization rates. Conversely, Suikkari et al. (11) reported that a small dose of FSH in women undergoing regular menstruation might increase the yield of immature oocytes collected. Junk et al. (12) also demonstrated in their study in 2003 that FSH priming improves oocyte maturation, but does not have an effect on subsequent embryonic development.

Studies on the effect of hcg priming on in vitro maturation also gave conflicting results. In 1999, Chian et al. (13) reported that giving 10,000 IU hcG 36 hours before oocyte collection as in standard IVF procedures improved the maturation rate of immature oocytes. They postulated that the oocyte maturation period in vitro was shortened and the rate of oocyte maturation was increased by priming with 10,000 IU hcg before oocyte collection. On the contrary, the study by Fadini et al. (8) in 2009 was not in favour of hcg priming alone in in vitro maturation, since it showed the lowest pregnancy and implantation rates. In the literature, there are two case reports published in which the cycles were on the edge of cancellation due to the improper use of hcg and ovarian hyperstimulation, but were rescued by IVM application (1,7). Also, Jiayin et al. (4) reported three cases in which in vitro matured oocytes retrieved from poor responders undergoing stimulation via in vitro fertilization cycles yielded healthy pregnancies and births. IVM was observed to act as a good alternative to cancellation in these cases. Our case seems to be a good example of delayed response to exogenous gonadotrophins and the application of in vitro maturation in poor responders. 
Although most of the clinical aspects of the technique were studied, the research on the best IVM culture conditions is still ongoing. Since culture conditions and the technique were not optimised adequately, the results of IVM cases are still poorer than conventional IVF, and IVM still stands as a technique that needs to be strengthened. Despite lower clinical outcomes compared to standard IVF techniques, IVM seems to be an attractive method for many patients with many advantages such as lower treatment costs, shorter schedule, no side effects with drugs, no OHSS risk and no patient discomfort (14). Because of these advantages, we believe that IVM could be a good alternative not only for PCOS patients but also for women with different aetiologies when the conditions are optimised.

Ethics Committee Approval: Ethics committee approval was received for this study.

Informed Consent: Written informed consent was obtained from patients who participated in this study.

Peer-review: Externally peer-reviewed.

Author contributions: Concept - E.Y., E.Ç., O.B. ; Design - E.Y., E.Ç., O.B..; Supervision - E.Y., E.Ç., O.B. Resource - E.Y., E.Ç., O.B..,; Materials - E.Y., E.Ç., O.B..,; Data Collection\&/or Processing - E.Y., E.Ç., O.B..; Analysis\&/or Interpretation - E.Y., E.Ç., O.B..; Literature Search - E.Y., E.Ç., O.B. Writing - E.Y., E.Ç., O.B. Critical Reviews - E.Y., E.Ç., O.B..

Acknowledgements: The authors would like to thank Assist. Prof. Yigit Cakiroglu for his valuable comments on the report.

Conflict of Interest: No conflict of interest was declared by the authors.

Financial Disclosure: No financial disclosure was declared by the authors.

\section{References}

1. Jaroudi KA, Hollanders JM, Sieck UV, Roca GL, El-Nour AM, Coskun S. Pregnancy after transfer of embryos which were generated from in-vitro matured oocytes. Hum Reprod 1997; 12: 857-9. [CrossRef]

2. Son WY, Tan SL. Laboratory and embryological aspects of Hcgprimed in vitro maturation cycles for patients with polycystic ovaries. Hum Reprod Update. 2010; 16: 675-89. [CrossRef]
3. Fridén B, Hreinsson J, Hovatta O. Birth of a healthy infant after in vitro oocyte maturation and ICSI in a woman with diminished ovarian response: case report. Hum Reprod 2005; 20: 2556-8. [CrossRef]

4. Liu J, Lu G, Qian Y, Mao Y, Ding W. Pregnancies and births achieved from in vitro matured oocytes retrieved from poor responders undergoing stimulation in in vitro fertilization cycles. Fertil Steril 2003; 80: 447-9. [CrossRef]

5. McElroy SL, Byrne JA, Chavez SL, Behr B, Hsueh AJ, Westphal LM, et al. Parthenogenic blastocysts derived from cumulus-free in vitro matured human oocytes. PLoS One 2010; 5: e10979. [CrossRef]

6. Son WY, Chung JT, Chian RC, Herrero B, Demirtas E, Elizur S, et al. A $38 \mathrm{~h}$ interval between hCG priming and oocyte retrieval increases in vivo and in vitro oocyte maturation rate in programmed IVM cycles. Human Reproduction 2008; 23: 2010-6. [CrossRef]

7. Liu J, Katz E, Garcia JE, Compton G, Baramki TA. Successul in vitro maturation of human oocytes not exposed to human chorionic gonadotrophin during ovulation induction, resulting in pregnancy. Fertil Steril 1997; 67: 566-8. [CrossRef]

8. Fadini R, Dal Canto MB, Mignini Renzini M, Brambillasca F, Comi R, Fumagalli $\mathrm{D}$, et al. Effect of different gonadotrophin priming on IVM of oocytes from women with normal ovaries: a prospective randomized study. Reprod Biomed Online 2009; 19: 343-51. [CrossRef]

9. Wynn P, Picton HM, Krapez JA, Rutherford AJ, Balen AH, Gosden RG. Pretreatment with follicle stimulating hormone promotes the numbers of human oocytes reaching metaphase II by in-vitro maturation. Hum Reprod 1998; 13: 3132-8. [CrossRef]

10. Lin YH, Hwang JL, Huang LW, Mu SC, Seow KM, Chung J, et al. Combination of FSH priming and HCG priming for in-vitro maturation of human oocytes. Hum Reprod 2003; 18: 1632-6. [CrossRef]

11. Suikkari AM, Tulppala M, Tuuri T, Hovatta O, Barnes F. Luteal phase start of low-dose FSH priming of follicles results in an efficient recovery, maturation and fertilization of immature human oocytes. Hum Reprod 2000; 15: 747-51. [CrossRef]

12. Junk SM, Dharmarajan A, Yovich JL. FSH priming improves oocyte maturation, but priming with FSH or Hcg has no effect on subsequent embryonic development in an in vitro maturation program. Theriogenology 2003; 59: 1741-9. [CrossRef]

13. Chian RC, Gülekli B, Buckett WM, Tan SL. Priming with human chorionic gonadotrophin before retrieval of immature oocytes in women with infertility due to the polycystic ovary syndrome. N Engl J Med 1999; 341: 1624-6. [CrossRef]

14. Lim JH, Yang SH, Xu Y, Yoon SH, Chian RC. Selection of patients for natural cycle in vitro fertilization combined with in vitro maturation of immature oocytes. Fertil Steril 2009; 91: 1050-5. [CrossRef] 